\title{
Sexual health and use of condoms among local and international sex workers in Sydney
}

\author{
C C O'Connor, G Berry, R Rohrsheim, B Donovan
}

Objectives: To compare indicators of sexual health and predictors of condom use for commercial sex among local and international female sex workers first attending an STD clinic.

Setting: A public STD clinic in Sydney, Australia.

Subjects: All sex workers first attending between June 1991 and May 1993.

Methods: Cross-sectional analysis of demographic, behavioural and morbidity data from proforma medical records.

Results: 91 local sex workers and 123 international sex workers (predominantly from Thailand, Malaysia and China) first presented during the study period. There were significantly higher prevalences of chlamydia ( $0 \mathrm{v} .15 \%, \mathrm{p}=0.0002)$, gonorrhoea $(0 \mathrm{v} .14 \%, \mathrm{p}=0.0006)$, syphilis $(0$ v. $10 \%, p=0.006)$ and clinical genital herpes $(0 \mathrm{v} .5 \%, \mathrm{p}=0.04)$ among international sex workers. The only case of HIV infection was in an international sex worker. Inconsistent condom use for commercial sex was significantly more common among international sex workers $(R R=4 \cdot 5 ; 95 \%$ CI 3.1-6.5). On multivariate analysis, inconsistent condom use in international sex workers was associated with a recent history of prostitution outside Australia $(p=0.04)$, while inconsistent condom usage among local sex workers was associated with increasing age $(p=0.003)$.

Conclusions: These data illustrate the efficacy of condoms and the success of targeted education programmes in local sex workers in Sydney. By contrast, international sex workers continued to be at high risk of STDs. The international sex industry in Sydney requires enhanced culture-specific interventions. Immigration laws as they affect sex workers should also be reviewed.

(Genitourin Med 1996;72:47-51)

Keywords: prostitution; Australia; STD; condom; migrants

\section{Introduction}

At the beginning of the 1980 s, when the AIDS epidemic was first emerging in Australia, Sydney's female sex workers incurred morbidity from sexually transmissible diseases (STD's) which was comparable to its Asian neighbours. ${ }^{12}$ This morbidity reflected high prevalences of bacterial STDs at a population level at that time in Australia ${ }^{3}$ and the rarity (less than $1 \%$ of transactions) of condom usage in brothels 1 - the major venues for commercial sex in Sydney.

Beginning with legislative reforms, a broadbased programme of public health activities that affected the sex industry was undertaken which mirrored all aspects of the Ottawa Charter for Health Promotion. ${ }^{4}$ This programme included partial decriminalisation of prostitution-related activities; the formation and (later) government-funding of sex worker community based organisations; general and targeted education programmes; free supply of safer sex and safe drug use equipment; and the creation and remodelling of health services to the needs of the sex industry. Absent from the programme was any reliance on contact tracing or coercive measures.

Thus, during the 1980 s increased condom use and decreased rates of acute STDs among sex workers in Sydney were documented..$^{5-8}$

However, from the mid-1980s the Sydney Sexual Health Centre (SSHC) saw increasing numbers of non-English speaking female sex workers who had recently arrived from Asian countries, particularly Thailand, Malaysia and mainland China. Outreach workers estimated that by 1992 there were between one and two thousand international sex workers in Sydney each year and probably about three hundred at any time. ${ }^{9}$ They comprised approximately $20 \%$ of female sex workers in Sydney. ${ }^{9}$

Previous impressions were that international sex workers in Sydney used condoms less consistently than their local counterparts. ${ }^{10}$ Not using condoms gave international sex workers a competitive edge when soliciting clients. When the resident sex industry heeded the safer sex message from the mid 1980 s, a market niche was probably created for sex workers who did not consistently practise safer sex. Notably, it was about this time that the international sex industry grew to its present size. The 1980 s also saw a rapid increase in Sydney's Asian population-a major client group of international sex workers. ${ }^{10}$

Few studies of sex workers in Sydney have included substantial numbers of international sex workers owing to difficulties in access, including language barriers. ${ }^{7}$ However, an earlier study concluded that $89 \%$ of gonorrhoea cases detected in female patients attending SSHC were among international sex workers. ${ }^{8}$

We embarked on the current study to more fully define the sexual health status and to ascertain levels and predictors of condom use among local and international sex workers at first visits to SSHC.

\section{Methods}

A review of the proforma case notes of all female sex workers who attended SSHC for a 
first visit between 1 June 1991 and 31 May 1993 was performed. These women were identified via the computerised database and demographic, behavioural, and morbidity data were extracted from the case notes for this analysis. All the women attended for STD screening, though sometimes prompted by symptoms. As Australian residency status was not routinely collected, we defined a local sex worker as a woman who was born in Australia or who spoke English at home, and reported herself to be currently engaged in prostitution. We defined an international sex worker as a current sex worker born outside Australia who did not speak English at home. Thus, the distinction between the two groups was predominantly on language and cultural grounds.

Gonococcal, ${ }^{11}$ chlamydial $^{12}$ and urinary tract infections were confirmed by culture. The diagnosis of genital herpes and candidiasis was made clinically or by culture. ${ }^{13}$ The diagnosis for trichomoniasis was by microscopy of fresh vaginal specimen. Pelvic inflammatory disease (PID) and genital warts were diagnosed clinically. Bacterial vaginosis was diagnosed on clinical and microbiological criteria. ${ }^{14}$ Serum from all women was tested for antibodies to hepatitis B core antigen (anti$\mathrm{HB}_{\mathrm{c}}$ ) using commercial enzyme immunoassay (EIA) technique (Abbotts, USA or General Biologicals, Taiwan). Those sera containing anti- $\mathrm{HB}_{\mathrm{c}}$ were then tested for hepatitis B surface antigen $\left(\mathrm{HB}_{\mathrm{S}} \mathrm{Ag}\right)$ by EIA (Sanofi Pasteur, France). The diagnosis of syphilis was made by clinical assessment and interpretation of the following serological tests: rapid plasma reagin (RPR) (CSL, Australia), Treponema pallidum haemagglutination (TPHA) (Serodia, Japan) and for confirmation-fluorescent treponemal

Table 1 Demographic characteristics of female sex workers

\begin{tabular}{|c|c|c|}
\hline & $\begin{array}{l}\text { Local } \\
n=91\end{array}$ & $\begin{array}{l}\text { International } \\
\mathrm{n}=123\end{array}$ \\
\hline $\begin{array}{l}\text { Age } \\
\text { mean }(\mathrm{SD}) \\
\text { median }\end{array}$ & $\begin{array}{l}25 \cdot 5(5 \cdot 7) \\
25\end{array}$ & $\begin{array}{l}25 \cdot 3(4 \cdot 5) \\
24\end{array}$ \\
\hline $\begin{array}{l}\text { Country of birth } \\
\text { Australia } \\
\text { New Zealand } \\
\text { United Kingdom } \\
\text { other Europe } \\
\text { Thailand } \\
\text { China } \\
\text { Malaysia } \\
\text { Singapore } \\
\text { other Asia } \\
\text { other } \\
\text { missing data }\end{array}$ & $\begin{array}{c}49(56 \%) \\
11(13 \%) \\
11(13 \%) \\
4(5 \%) \\
1(1 \%) \\
0 \\
1(1 \%) \\
1(1 \%) \\
6(7 \%) \\
3(4 \%) \\
4\end{array}$ & $\begin{array}{l}0 \\
0 \\
0 \\
1(1 \%) \\
60(49 \%) \\
26(21 \%) \\
28(23 \%) \\
6(5 \%) \\
2(2 \%) \\
0 \\
0\end{array}$ \\
\hline $\begin{array}{l}\text { Language spoken at home } \\
\text { English } \\
\text { Thai } \\
\text { Chinese } \\
\text { other Asian } \\
\text { other european } \\
\text { missing data }\end{array}$ & $\begin{array}{l}89(99 \%) \\
0 \\
0 \\
0 \\
1(1 \%) \\
1\end{array}$ & $\begin{array}{l}0 \\
59(48 \%) \\
62(51 \%) \\
1(1 \%) \\
1(1 \%) \\
1\end{array}$ \\
\hline $\begin{array}{l}\text { Interpreter requested } \\
\text { missing data }\end{array}$ & $\begin{array}{l}0 \\
2\end{array}$ & $\underset{1}{94}(77 \%)$ \\
\hline $\begin{array}{l}\text { Education } \\
\text { Primary only } \\
\text { missing data }\end{array}$ & $\begin{array}{l}0 \\
5^{\star}\end{array}$ & $\begin{array}{l}24(28 \%) \\
37^{\star}\end{array}$ \\
\hline $\begin{array}{l}\text { Current alcohol use } \\
\text { missing data }\end{array}$ & $\begin{array}{c}54(59 \%) \\
0\end{array}$ & $\begin{array}{c}39(32 \%) \\
0\end{array}$ \\
\hline $\begin{array}{l}\text { IV drug use (ever) } \\
\text { missing data }\end{array}$ & $\begin{array}{l}6(7 \%) \\
0\end{array}$ & $\begin{array}{l}0 \\
0\end{array}$ \\
\hline
\end{tabular}
during the study period. antibody absorbed test (FTA-Abs) (Biomerieux, France). Human immunodeficiency virus (HIV) antibody testing was by EIA (Serodia, Japan) with Western blot confirmation.

Statistical analysis of the contingency tables was by the chi square test, with Yates's correction for $2 \times 2$ tables. Fisher's exact test was used when expected frequencies were less than 5. For an ordered categorical notable the Mantel Haenszel chi-square test for trend was employed. Condom use in relation to a number of predictor variables was examined by logistic regression. Epi-Info, SPSS and SAS statistical packages were employed.

The study was approved by Eastern Sydney Area Health Service Research Ethics Committee.

\section{Results}

\section{Demographic and lifestyle variables}

During the 1991-93 study period 91 "local" and 123 "international" sex workers attended SSHC for the first time. The two groups were of similar average ages (table 1), though there was a relative clustering of international sex workers in the $21-25$ year age grouping, $47 \%$ compared with $34 \%$. The local sex workers spoke English almost exclusively at home, whereas almost all the international sex workers spoke Thai or a Chinese dialect (table 1). As defined, most of the local sex workers were from Australia, New Zealand or the UK but $10 \%$ were born in Asia. More than $90 \%$ of the international sex workers were born in Thailand, Malaysia, or China and over three quarters requested an interpreter (table 1). The Sexual Health Centre holds weekly Thai and Chinese language clinics with experienced interpreters. The local sex workers were more highly educated on every parameter (not shown here), highlighted by the fact that over a quarter of international and none of the local women had only a primary education (table 1). While $7 \%$ of the local sex workers had a history of injecting drug use, no injecting drug use was reported by any of the international sex workers (table 1). Heavy alcohol use was uncommon in either group (data not shown).

Prior sexual health markers

Oral contraceptives were more commonly used by international sex workers while local sex workers were more likely to rely on condoms for contraception and STD prevention (table 2). International sex workers were less likely to report a previously diagnosed STD or have previously had cervical cytology performed, perhaps reflecting more limited access to health care services (table 2). The reported levels of previous HIV testing in both groups were similarly high (table 2). None of the women had previously tested HIV positive.

\section{Current STDs}

At first visit by international sex workers about one in seven were diagnosed with gonorrhoea and a similar proportion with chlamydia. No cases of either were diagnosed in local sex 
Table 2 Indicators of prior sexual health in female sex workers

\begin{tabular}{llll}
\hline & $\begin{array}{l}\text { Locals } \\
n=91^{\star}\end{array}$ & $\begin{array}{l}\text { International } \\
n=123^{\star}\end{array}$ & $p$ \\
\hline Contraception & & & \\
oral & $33(38 \%)$ & $85(71 \%)$ & $<0.001$ \\
condoms & $53(61 \%)$ & $22(18 \%)$ & $<0.001$ \\
Previous STDs & $67(74 \%)$ & $54(44 \%)$ & $<0.001$ \\
Previous cervical cytology & $82(95 \%)$ & $43(35 \%)$ & $<0.001$ \\
Previous HIV test & $70(77 \%)$ & $87(71 \%)$ & 0.4 \\
\hline
\end{tabular}

${ }^{\star}$ data missing on $0-5 \%$ of variables.

Table 3 Prevalence of STDs among female sex workers

\begin{tabular}{llll}
\hline & $\begin{array}{l}\text { Local } \\
n=91\end{array}$ & $\begin{array}{l}\text { International } \\
n=123\end{array}$ & $p$ \\
\hline Gonorrhoea (all sites) & 0 & $17(14 \%)^{\star}$ & $0 \cdot 0006 \ddagger$ \\
Gonorrhoea (urogenital) & 0 & $14(11 \%)$ & $0 \cdot 002 \ddagger$ \\
Chlamydia & 0 & $19(15 \%)$ & $0.0002 \ddagger$ \\
Trichomoniasis & 0 & $1(1 \%)$ & $1 \cdot 0 \ddagger$ \\
Pelvic inflammatory disease & $2(2 \%)$ & $10(8 \%)$ & $0 \cdot 1 \ddagger$ \\
Syphilis all stages & 0 & $12(10 \%) \dagger$ & $0.006 \ddagger$ \\
Clinical genital herpes & 0 & $6(5 \%)$ & $0.04 \S$ \\
Chronic hepatitis B & $2(2 \%)$ & $4(3 \%)$ & $1.0 \S$ \\
Genital warts & $5(6 \%)$ & $9(7 \%)$ & $0.8 \ddagger$ \\
HIV & 0 & $1(1 \%)$ & $1.0 \rrbracket$ \\
\hline
\end{tabular}

*Including 3 pharyngealinfections, fone secondary syphilis, all others latent.

$\ddagger$ Yates's Corrected Method.

§Fisher's Exact Method; the two-sided p value contains those tables in the other tail which are no more likely than the observed table.

Table 4 Prevalence of other genitourinary conditions in female sex workers

\begin{tabular}{llll}
\hline & $\begin{array}{l}\text { Local } \\
n=91\end{array}$ & $\begin{array}{l}\text { International } \\
n=123\end{array}$ & $p$ \\
\hline Candidiasis & $9(10 \%)$ & $16(13 \%)$ & $0 \cdot 6^{\star}$ \\
Bacterial vaginosis & $7(8 \%)$ & $5(4 \%)$ & $0 \cdot 4^{\star}$ \\
Urinary tract infection & 0 & $3(2 \%)$ & $0 \cdot 3 \dagger$ \\
\hline
\end{tabular}

*Yates's Corrected Method.

†Fisher's Exact Method; the two-sided p value contains those tables in the other tail which are no more likely than the observed table.

Table 5 Consistent condom use for vaginal or anal sex in the last 3 months

\begin{tabular}{llcl}
\hline & Local & International & Relative rate of use $(95 \%$ CI) \\
\hline Commercial sex $^{\star}$ & $66 / 72(92 \%)$ & $22 / 107(21 \%)$ & $4 \cdot 5$ \\
All partners $\dagger$ & $47 / 87(54 \%)$ & $8 / 107(8 \%)$ & $\begin{array}{l}7 \cdot 2 \\
(3 \cdot 6-14 \cdot 5)\end{array}$ \\
& & & \\
\hline
\end{tabular}

*Missing data on $13-21 \%$

†Missing data on $4-13 \%$.
Overall there were only nine STD diagnoses made in local sex workers compared with 79 for international sex workers $(\mathrm{p}<0.001)$. In $83(91 \%)$ local and $66(54 \%)$ international sex workers no STD diagnosis was made $(\mathrm{p}<$ $0.001)$.

\section{Other genitourinary conditions}

There was no statistical difference in the prevalence of those genitourinary conditions which are not sexually transmitted-bacterial vaginosis, candidiasis or urinary tract infections (table 4).

\section{History of prostitution}

Forty seven percent of international sex workers had reported working overseas as a prostitute in the previous twelve months whereas only $10 \%$ of local sex workers did $(p<0.001)$. Those international sex workers born in Malaysia were significantly more likely $(p<$ 0.001 ) and those born in China were significantly less likely $(p<0.01)$ to have worked overseas in the last 12 months compared to other international sex workers.

\section{Condom use patterns}

Over half the local sex workers but only $8 \%$ of international sex workers reported consistently using condoms for vaginal and anal sex (both commercial and with private partners) in the prior three months $(\mathrm{p}<0.001)$ (table 5). Ninety-two percent of the local sex workers reported using condoms all the time for commercial vaginal and anal sex during the three months while only $21 \%$ of the international sex workers reported doing so $(p<0.001)$ (table 5). Only one local and no international sex workers reported commercial anal sex during the previous three months. The pattern of condom usage for oral sex mirrored the patterns for vaginal sex in both groups (data not shown).

On univariate analysis failure to use condoms consistently for recent commercial sex for all of the women was positively associated with those factors that were associated with being an international sex worker, that is, having worked as a prostitute overseas in the last 12 months, country of birth, education level, and the need for an interpreter. Multivariate analysis of the entire group was unproductive because of problems of collinearity. Accordingly further analysis aimed at identifying other features that were associated with condom use were carried out within local and international sex worker groups separately.

On univariate and multivariate analysis inconsistent condom usage for commercial vaginal and anal sex during the last three months in local sex workers was associated with increasing age ( $p=0.003)$, but not country of birth, or education level, or a history of overseas prostitution in the last twelve months. All six local sex workers who did not consistently use condoms for commercial sex were older than 26 years. Among the international sex workers inconsistent condom use was independently correlated with a history of prostitution overseas in the last 12 months ( $p$

Significantly more international sex workers had multiple STD diagnoses - only one $(1 \%)$ local sex worker compared to eighteen $(15 \%)$ international sex workers was diagnosed with more than one STD at first visit $(p=0.001)$. 
$=0.04$ ), but not country of birth, education level, or the need for an interpreter. Condoms were used consistently by $11 \%$ of those who had a history of overseas prostitution in the last twelve months and $30 \%$ of those who did not.

\section{Discussion}

This study confirmed the ongoing dramatic fall in the prevalence of STDs among local sex workers in Sydney over the last ten years suggested by other reports. ${ }^{578}$

The study also documented higher prevalences of most bacterial STDs among international sex workers, attributable to inconsistent condom use for commercial sex. Studies in Europe, the USA, Asia and Africa have documented women moving from poor to more affluent countries for sex work. These studies have typically shown much higher rates of STDs in the immigrant women. ${ }^{15-18}$ It was particularly worrying to find that inconsistent condom use was most common (89\%) for women who had worked as prostitutes overseas in the last twelve months, often in countries with large or emerging heterosexually acquired HIV epidemics.

The study also found that among local sex workers inconsistent condom use is associated with increasing age. Older women tend to be independent operators and to have small stable clientele. Another study also suggested that sex workers use condoms less consistently with regular clients. ${ }^{19}$

Other than condom use, what other factors could have produced the contrasting STD prevalence rates between local and international sex workers? Australia has universal health insurance for its permanent residents. Thus most local sex workers would have access to free or low cost health care through general practitioners making them more likely to have previously availed themselves to other services. This would account for their higher reported previous STD diagnoses (table 2) and contribute to lower STD prevalences in the current study. By contrast, international sex workers usually do not have access to STD screening other than through public sexual health services. However, the most marginalised of the international sex workers with the highest STD prevalence may not even have access to information about the existence of free sexual health services. Thus in this study opposing biases may act on international sex workers selecting women with lower and higher STD prevalence rates.

Another possibility was that symptoms may have had a differential effect on the women seeking STD screening. This would inflate the STD prevalence in one or other group. However, of the conditions which are typically symptomatic (PID, vaginal canditions, genital warts or herpes) only clinical genital herpes was statistically more likely to be present in international sex workers. But with all symptomatic conditions taken together, the international sex workers were probably moderately more symptomatic overall.
Sex workers in Sydney who are also injecting drug users (IDUs) and/or are street workers are concentrated around the Kings Cross area. These women are predominantly seen at Kirketon Road Centre, a targeted primary health care facility. Thus this study may have underrepresented more marginalised local sex workers who may have higher prevalences of STDs than the local sex workers attending our service.

Information was not collected on the prophylactic use of antibiotics, a common practice by sex workers in Asia where antibiotics are obtainable over-the-counter. In Australia antibiotics are prescription items only and we have never suspected systematic self-medication by sex workers. If self medication occurred at all it would have been among international sex workers and have tended to dilute the major findings of the current study.

Because the study measured prevalence and not incidence of STD infections, women coming from countries with higher background STD prevalences than Australia would be expected to have higher prevalences at their first visit. These differing national prevalences were almost certainly the reason for significantly higher levels of syphilis in international sex workers. We have embarked on further (incidence) studies to determine the extent to which these high rates of infections are due to direct importation or to the international sex workers' behaviour and clientele once they start working in Sydney.

The findings may also be complicated by differing prevalences of STD in the clients of local and international sex workers. Little is known about the prevalence of STDs in Sydney's Asian communities who compromise the majority of the clients and private partners of international sex workers. ${ }^{10}$

Approximately half of the international sex workers in this study were from Thailand. Many of these women come from poor rural families with dependent parents, children and siblings. Brockett and Murray reported that many Thai sex workers in Sydney have not worked in the sex industry before arrival in Australia and consequently have little knowledge of STDs or safer sex. ${ }^{10}$

About one quarter of the international sex workers were ethnic Chinese women from Malaysia or Singapore. These women spoke Cantonese. Preliminary impressions were that they often stay for shorter periods than the Thai sex workers. They were also significantly more likely to have previously worked in prostitution in a circuit that may include Japan and Singapore. ${ }^{9}$ Most of the remainder of the international sex workers were from mainland China, and were part of a large group that were granted long term visas following the Tienamen Square incident in 1989. These women usually speak Mandarin. Unlike other international sex workers these women were not illegal immigrants and did not originally come to Australia for the purposes of prostitution. Chinese-speaking sex workers were more likely to be employed in smaller, less obvious brothels than the Thai women so have tended 
to be under-represented in community-based surveys. ${ }^{9}$

When international sex workers commence prostitution in Australia they are in a very disempowered position. The vast majority do not speak English. Many have minimal literacy skills in their own language, so even written education material in Thai or Chinese may be of limited value to them. Thai and Malaysian women are sometimes bound by contracts that require them to earn large amounts of money for their employers before they are allowed to keep any for themselves (typically $\$$ A20,000). ${ }^{9}$ Their work sites are concentrated in the inner city and the western suburbs of Sydney, areas accessible to local Asian communities, who create much of the demand for their services. ${ }^{9}$

Many international sex workers are moved from one brothel to another, even one state to another, to avoid scrutiny by immigration officials. Thus, they can be difficult to contact for safe sex education. Moving around also perpetuates their disempowerment as they cannot build support networks. ${ }^{9}$

More qualitative data are required on the factors affecting international sex workers before their arrival and during their stay in Australia. Little information is available on the clients of international sex workers in Australia. Further study will help to refine targeted interventions for both groups.

In response to the low condom usage rates and high STD rates among international sex workers, the Multicultural Health Promotion Project was developed by the SSHC during 1990 and implemented in 1991 in conjunction with other sexual health services and the community-based Sex Workers Outreach Project. Through direct visits to sex industry establishments, staff of the Project encourage safer sex through the provision of free condoms, lubricant and educational material such as language and culture-specific comics and videos. In 1994 SSHC also commenced a project targeting the Vietnamese male clients of international sex workers.

This study indicated that some policy change should be considered. Although sex workers in Sydney are now less marginalised by the laws dealing with prostitution, ${ }^{4}$ international sex workers are effectively marginalised by the immigration laws. Federal police raids and mass deportation of these women are commonplace. The net effect is a constant stream of new women arriving (and staying) illegally who are wary of authorities, and thus difficult to access for health promotion purposes. As suggested by this study, the most recently arrived women are the least likely to consistently use condoms. In the absence of action required to legitimise the international sex industry, it will continue to be a potential bridge from the Asian HIV epidemics into Sydney's heterosexual populations.

1 Donovan B. Gonorrhoea in a Sydney house of prostitution. Med F Aust 1984;140:268-71.

2 Jones R. STDs in prostitutes. Med F Aust 1984;140:303-4.

3 Hart G. STD epidemiology in Australasia: syphilis and gonorrhoea. Venereology 1992;5:115-20.

4 Donovan B, Harcourt C. The female sex industry in Donovan B, Harcourt C. The female sex industry in
Australia: a health promotion model. Venereology 1995 (in press).

5 Philpot CR, Harcourt JM, Edwards JM. A survey of female prostitutes at risk of HIV infection and other sexually transmissible diseases. Genitourin Med 1991;67:384-8.

6 Lovejoy F, Perkins R, Corduff Y, Dean MJ, Wade A. AIDS preventive practices among female prostitutes and their clients and private risk. Part 1: A Survey of 280 prostitutes in New South Wales and the Australia Capital Territory. Report to the Dept of Health, Housing \& Community Services. Sydney, University of New South Wales 1991:3-5.

7 Harcourt C, Philpot CR. Female Prostitution, AIDS, Drugs and Alcohol in New South Wales. In: Plant $M$ (ed). AIDS, Drugs and Prostitution. London, Routledge (ed). AIDS, Drugs
1990:132-154.

8 Donovan B, Harcourt C, Bassett I, Philpot CR. Gonorrhoea and Asian prostitution: the Sydney Sexua Health Centre experience. Med f Aust 1991;154:520-1.

9 Brockett L, Murray A. Sydney's Asian sex workers: AIDS and the geography of a new underclass. Asian Geographer 1993;12:83-95.

10 Brockett L, Murray A. Thai sex workers in Sydney. In: Perkins R, Prestage G, Sharp R, Lovejoy F (eds). Sex Work and Sex Workers in Australia. Sydney, UNSW Press. 1994:191-202.

11 Australian Gonococcal Surveillance Program. Penicillin sensitivity of gonococci in Australia: development of the Australian Gonococcal Surveillance Program. $\mathrm{Br} f$ Venereal Dis 1984;60:226-30.

12 Stamm WE, Tam M, Koester M, Cles L. Detection of $C$. trachomatis inclusions in tissue culture using fluoresceinconjugated antibodies. $\mathcal{F}$ Clin Microbiol 1984;17:666-8.

13 Moseley RC, Corey L, Benjamin D, Winter C, Remington $M$. Comparison of viral isolation, direct immunofluorescence, and indirect immunoperoxidase techniques for the detection of genital herpes simplex virus infection. $\mathcal{F}$ Clin Microbiol 1981;13:913-8.

14 Hillier S, Holmes KK. Bacterial vaginosis. In: Holmes $\mathrm{KK}$ Mårdh P-A, Sparling PF, et al (eds). Sexually Transmitted Diseases 2nd ed New York: McGraw Hill 1990:547-59.

15 Nayyar K, Cummings M, Weber J, Bernes S, Stolz E, Feldman Y, McCormick W. Prevalence of genital pathogens among female prostitutes in New York City pathogens among female prostitutes in New York
and in Rotterdam. Sex Transm Dis 1986;13:105-7.

16 Nanki P, M'Boup S, Marlink R, et al. Prevalence and risk determinants of human immunodeficiency virus type 2 (HIV-2) and human immunodeficiency virus type 1 (HIV-1) in west african female prostitutes. $A m \mathcal{f}$ Epidemiol 1992;136:895-907.

17 van Haastrecht HJA, Fennema JSA, Coutinho RA, van der Helm TCM, Kint JAPCM, van den Hoek JAR. HIV prevalence and risk behaviour among prostitutes and clients in Amsterdam: migrants at increased risk of HIV infection. Genitourin Med 1993;69:251-6.

18 Stary A, Kopp W, Söltz-Szöts J. Medical Health Care of Viennese Prostitutes. Sex Transm Dis 1991;18:159-65.

19 Morris M, Pramualratana A, Podhisita C, Wawer MJ. The relational determinants of condom use with commercial sex workers in Thailand. AIDS 1995;9:507-16. 